\title{
Ecstasy Use Among Hispanic and Black Substance Users in New York City
}

\author{
DANIELLE C. OMPAD, SANDRO GALEA, \\ CRYSTAL M. FULLER, VINCENT EDWARDS, \\ AND DAVID VLAHOV
}

Center for Urban Epidemiologic Studies, New York Academy of Medicine, New York, New York, USA

\begin{abstract}
Surveillance data suggests that use of ecstasy in the U.S. is predominantly among white adolescent and young adults. To investigate ecstasy use among substance users in New York City we added questions to ongoing efforts to recruit heroin and cocaine users. Of 715 participants recruited, $58.3 \%$ were injection dug users (IDUs). The median age was 32 (range 17-64), 76.4\% were male, $49.0 \%$ were currently homeless, $62.4 \%$ were Hispanic, $27.3 \%$ were black, and $34.5 \%$ were born outside the United States. Overall, $23.4 \%$ used ecstasy in their lifetime and $11.9 \%$ had used in the last-6 months. In multivariate logistic regression, correlates of lifetime ecstasy use included younger age, being born in the U.S., and current homelessness. We observed a significant interaction between injection drug use and race where, compared to black non-IDUs, Hispanic non-IDUs, and white IDUs were significantly more likely to have a history of lifetime ecstasy use while black IDUs were significantly less likely. These findings are limited to persons who use other drugs, but suggest that further investigation of ecstasy use in minority populations is warranted.
\end{abstract}

Keywords MDMA; ecstasy; minority health; substance use; epidemiology

\section{Introduction}

Club drugs have been a growing concern in the United States since the 1980s. Although a number of psychoactive agents have been referred to as "club drugs," the most common substances encompassed by the term are: ecstasy (3,4-methylenedioxymethamphetamine or MDMA), GHB (gamma-hydroxybutyrate), ketamine, LSD (lysergic acid diethylamide), methamphetamines, PCP (phencyclidine), and Rohypnol ${ }^{\circledR}$ (flunitrazepam). Currently available data suggest that ecstasy use in the United States is most common (Arria et al., 2002; Yacoubian, 2002). Recently, national surveillance data have suggested that ecstasy use is declining among adolescents (Johnston, O’Malley, and Bachman, 2002). However, these observations arise from studies conducted among predominantly white populations. With the exception of the national surveillance studies (e.g., Monitoring the Future Study, National Household Survey on Drug Abuse), most domestic studies have been conducted among rave or circuit party attendees (Arria et al., 2002; Colfax et al., 2001; Mansergh et al., 2001; Mattison et al., 2001), and men who have sex with men (Colfax et al., 2001;

Address correspondence to Danielle C. Ompad, New York Academy of Medicine, Center for Urban Epidemiologic Studies, 1216 Fifth Avenue, New York, New York 10029, USA. E-mail: dompad@ nyam.org 
Mansergh et al., 2001; Mattison et al., 2001; Klitzman, Pope, and Hudson, 2000), most of whom are white.

There is emerging evidence that the club drug economy may be changing. Recent reports have documented the movement of club drugs from clubs and raves to the streets. The National Institute on Drug Abuse's Community Epidemiology Working Group has reported that ecstasy was moving from the clubs to the street in several cities, including Baltimore and New York (Community Epidemiology Work Group, 2001). In light of these changes in drug use availability and the paucity of data available among minorities, we investigated the use of ecstasy among minority substance users in New York City (N.Y.C.). To investigate whether or not to conduct major efforts to estimate ecstasy use in minority communities, we chose to start with a survey of use within an ongoing project that involves recruitment of injectors as well as noninjectors of heroin or cocaine within two minority communities. This sampling was not considered representative of the respective communities but was meant to provide an indication of the presence of ecstasy that may then warrant closer attention.

\section{Method}

\section{Research Sample}

Between October 2002 and September 2003, we interviewed substance users participating in three ongoing observational studies in N.Y.C. Eligibility for the parent studies included age, $\geq 15$ years old and recent (past 2 months) use of heroin, crack, or cocaine more than monthly. Recruitment involved targeted sampling with street outreach techniques, and data collection was conducted at two stationary storefronts in Central Harlem (Manhattan) and the South Bronx and a recreational vehicle that parked in Brooklyn, the Lower East Side of Manhattan, and Queens, all in N.Y.C. Recruitment methods used in these studies have been described in more detail elsewhere (Diaz et al., 2001a; Diaz et al., 2001b). This study was approved by the Institutional Review Board at the New York Academy of Medicine.

\section{Data Collection}

After providing informed consent, participants completed an interviewer-administered questionnaire that elicited information on demographic characteristics and drug use (i.e., type, frequency, duration). A supplemental questionnaire was added to ongoing studies to elicit detailed information on club drug use. Participants were reimbursed $\$ 20$ for participation in the study.

\section{Statistical Analysis}

Bivariate analyses were conducted to assess the relation between demographic and club drug use variables by race using chi-square statistics for categorical variables and ANOVA for continuous variables. Covariates that were significantly associated with use of ecstasy in bivariate analyses $(\mathrm{p}<0.2)$ were entered into a multivariate logistic model. Variables were retained in the final model if they were significant at the $p=0.10$ level. Potential interactions were examined, including race and country of birth and race and injection drug use. All analyses were conducted using Intercooled STATA 7 (Stata Corp., College Station, Texas).

\section{Results}

Between October 2002 and September 2003, we recruited 715 substance users. Among these, $546(76.4 \%)$ were male and $169(23.6 \%)$ were female. Hispanics were the 
Table 1

Selected demographic characteristics and ecstasy use among 715 substance users in New York City, October 2002-March 2003

\begin{tabular}{lcccrr}
\hline & & Hispanic & Black & White & \\
& $\mathrm{N}=715$ & $\mathrm{~N}=446$ & $\mathrm{~N}=195$ & $\mathrm{~N}=74$ & p-value \\
\hline Gender & & & & & \\
$\quad$ Male & $546(76.4)$ & $363(81.4)$ & $140(71.8)$ & $43(58.1)$ & $<0.001$ \\
$\quad$ Female & $169(23.6)$ & $83(18.6)$ & $55(28.2)$ & $31(41.9)$ & \\
$\leq 25$-years old & $179(25.0)$ & $129(28.9)$ & $28(14.4)$ & $22(29.7)$ & $<0.001$ \\
U.S. born & $468(65.9)$ & $231(52.1)$ & $176(90.7)$ & $61(83.6)$ & $<0.001$ \\
Lived in New York $<1$ year & $85(11.9)$ & $73(16.4)$ & $5(2.6)$ & $7(9.5)$ & $<0.001$ \\
Currently homeless & $350(49.0)$ & $218(49.0)$ & $91(46.7)$ & $41(55.4)$ & 0.441 \\
Dropped out of school & $492(74.5)$ & $354(79.8)$ & $137(79.7)$ & $39(53.4)$ & $<0.001$ \\
High school diploma & $325(45.5)$ & $168(37.8)$ & $108(55.4)$ & $49(66.2)$ & $<0.001$ \\
$\quad$ & & & & \\
$\quad$ or equivalent & $690(96.5)$ & $440(98.7)$ & $177(90.8)$ & $73(98.7)$ & $<0.001$ \\
Lifetime heroin use & $619(86.6)$ & $376(84.3)$ & $174(89.2)$ & $64(93.2)$ & 0.050 \\
Lifetime crack use & $695(97.2)$ & $433(97.1)$ & $188(96.4)$ & $74(100.0)$ & 0.272 \\
Lifetime cocaine use & $416(58.3)$ & $288(64.7)$ & $65(33.3)$ & $63(85.1)$ & $<0.001$ \\
Lifetime injection drug use & $183(25.6)$ & $119(26.7)$ & $31(15.9)$ & $33(44.6)$ & $<0.001$ \\
Lifetime ecstasy use & $22.0(6.7)$ & $22.5(6.5)$ & $22.7(8.1)$ & $19.8(5.7)$ & 0.087 \\
Mean age at first ecstasy & & & & & \\
$\quad$ use (SD) & $85(11.9)$ & $61(13.7)$ & $15(7.7)$ & $9(12.2)$ & 0.098 \\
Current (last 6 months) & & & & & \\
$\quad$ ecstasy use & & & &
\end{tabular}

predominant racial group (62.4\%), followed by blacks $(27.3 \%)$ and whites $(10.3 \%)$. The median age at enrollment was 32 (range 17-64). Half (49.0\%) were currently homeless. One-third (34.5\%) had been born outside the United States, and $11.9 \%$ had lived in New York City for less than a year. The proportion of the substance users that injected drugs was $58.3 \%$. Overall, $25.6 \%$ reported using ecstasy in their lifetime and $11.9 \%$ had used it in the last 6 months.

We assessed racial differences in demographic characteristics and ecstasy use (Table 1). Hispanics were significantly more likely than blacks and whites to be male $(81.4 \%$ vs. $71.8 \%$ and $58.1 \%$, respectively) and to have lived in New York City for less than a year (16.4\% vs. $2.6 \%$ and $9.5 \%$, respectively) and less likely to have been born in the U.S. (52.1\% vs. $90.7 \%$ and $83.6 \%, \mathrm{p}<0.001)$. Blacks tended to be older; whites were more likely to have a high school diploma (or equivalent) and less likely to have dropped out of school. In terms of substance use, whites were more likely than Hispanics and blacks to have a lifetime history of both ecstasy use (44.6\% vs. $26.7 \%$ and $15.9 \%$, respectively) and crack use (93.2\% vs. $84.3 \%$ and $89.2 \%$, respectively) as well as to have a history of injection drug use $(85.1 \%$ vs. $64.7 \%$ and $33.3 \%$, respectively). Compared to blacks, whites and Hispanics were more likely to have used ecstasy in the last 6 months, although this association was not significant $(\mathrm{p}=0.098)$. Among the 85 people who had used ecstasy in the last 6 months, $47(55.3 \%)$ had used once a month or less, $13(15.3 \%)$ had used 2 to 3 days a month, 11 (12.9\%) had used about once per week or 2 to 3 days per week, two (2.4\%) had used 4 to 6 days per week, and one (1.2\%) had used everyday. 
Table 2

Multivariate logistic regression model for correlates of lifetime ecstasy use among 642 Hispanic and black substance users in New York City, October 2002-March 2003

\begin{tabular}{lcc}
\hline & \multicolumn{2}{c}{ Lifetime ecstasy use } \\
\cline { 2 - 3 } & Crude OR (95\% CI) & Adjusted OR (95\% CI) \\
\hline Age $\leq 25$ & $4.49(3.11,6.48)$ & $4.26(2.87,6.33)$ \\
U.S. born & $1.21(0.84,1.74)$ & $1.65(1.08,2.54)$ \\
Currently homeless & $1.67(1.19,2.34)$ & $1.56(1.08,2.27)$ \\
Race & 1.0 & - \\
Black & $1.93(1.24,2.98)$ & - \\
Hispanic & $4.26(2.34,7.74)$ & - \\
White & $0.73(0.52,1.02)$ & 1.0 \\
Injection drug use & - & $2.07(1.16,3.67)$ \\
Race by injection drug use interaction & - & $1.57(0.41,6.01)$ \\
Black noninjector & - & $0.24(0.07,0.82)$ \\
Hispanic noninjector & - & $1.13(0.64,1.97)$ \\
White noninjector & - & $3.08(1.536 .18)$ \\
Black injector & - & \\
Hispanic injector & & \\
White injector & & \\
\hline
\end{tabular}

${ }^{a}$ Last 6 months.

We next constructed a multivariate logistic regression model to examine correlates of lifetime ecstasy use (Table 2). Ecstasy users were more likely to be 25 years old or younger [Adjusted Odds Ratio $(\mathrm{AOR})=4.26,95 \%$ Confidence Interval $(\mathrm{CI}): 2.87,6.33$ ], born in the U.S. (AOR $=1.65,95 \%$ CI: $1.08,2.54)$, and currently homeless $(\mathrm{AOR}=1.56,95 \%$ CI: $1.08,2.27)$. We observed a significant interaction between injection drug use and race where, compared to black noninjectors, Hispanic noninjectors and white injectors were significantly more likely to have a history of lifetime ecstasy use (AOR $=2.07,95 \% \mathrm{CI}$ : 1.16, 3.67 and $\mathrm{AOR}=3.08,95 \% \mathrm{CI}: 1.53,6.18$, respectively), while black injectors were significantly less likely (AOR $=0.24,95 \%$ CI: $0.07,0.82$ ). The Pearson $\chi^{2}$ goodness-of-fit test for the estimated model indicated that we could not reject the model $(\mathrm{p}=0.1457)$.

Finally, we constructed a multivariate logistic regression model to examine correlates of recent ecstasy use (Table 3). Compared to blacks, Hispanics were significantly more likely to have used ecstasy in the last 6 months (AOR $=2.13,95 \% \mathrm{CI}: 1.11,4.09)$. Ecstasy users were more likely to be under 25 years old (AOR $=4.66,95 \%$ CI: 2.87, 7.55), currently homeless (AOR $=1.60,95 \% \mathrm{CI}: 0.98,2.61)$, but less likely to be an injection drug user $(\mathrm{AOR}=0.39,95 \% \mathrm{CI}: 0.34,0.66)$. We did not observe any significant interactions. The Pearson $\chi^{2}$ goodness-of-fit test for the estimated model indicated good model fit $(\mathrm{p}=$ $0.7620)$.

\section{Discussion}

To date, evidence of club drug use among minority populations, and ecstasy use in particular, is sparse. What little evidence there is suggests that, in broader population contexts, Asians were more likely and blacks were less likely than whites to have used ecstasy in the past 
Table 3

Multivariate logistic regression model for correlates of recent ${ }^{a}$ ecstasy use among 642 Hispanic and black substance users in New

York City, October 2002-March 2003

\begin{tabular}{lcc}
\hline & Crude OR $(95 \%$ CI) & Adjusted OR (95\% CI) \\
\hline Age $\leq 25$ & $5.24(3.27,8.39)$ & $4.66(2.87,7.55)$ \\
Currently homeless & $1.66(1.04,2.63)$ & $1.60(0.98,2.61)$ \\
Race & & \\
$\quad$ Black & 1.0 & 1.0 \\
$\quad$ Hispanic & $1.90(1.05,3.44)$ & $2.13(1.11,4.09)$ \\
$\quad$ White & $1.66(0.69,3.98)$ & $2.06(0.78,5.43)$ \\
Injection drug use & $0.51(0.32,0.80)$ & $0.39(0.34,0.66)$ \\
\hline
\end{tabular}

${ }^{a}$ Last 6 months.

year (Boyd, McCaben, and d'Arcy, 2003). Data from the Monitoring the Future (MTF) Study found that ecstasy users in the general population are overwhelmingly white, where between 89 and $91 \%$ of 12-month ecstasy users were white (Yacoubian, Jr., 2002). While at least $30 \%$ of these samples are non-white, they represent students attending high school (Yacoubian, Jr., 2002) or college (Boyd, McCaben, and d'Arcy, 2003). In our study, whites reported a higher prevalence of lifetime ecstasy use (44.6\%). However, lifetime history of ecstasy use was common among street-recruited Hispanic and black users of heroin, cocaine, and crack in New York City (26.7\% and $15.9 \%$, respectively).

Caution is needed in interpreting data from this study, as our sample included persons selected for using other illicit drugs. This data then should not be construed as generalizing to minority communities in general. What the data suggest instead is that street-based ecstasy use is present at least in some measure within a subset of illicit drug users from predominantly minority communities. Much of the current knowledge of the epidemiology of ecstasy use relies on surveillance studies like the MTF Study, which samples public and private school students in the United States (Johnston, O'Malley, and Bachman, 2002). In our sample, only $46.1 \%$ had finished high school (or equivalent), and $77.0 \%$ had dropped out of school at least once. Whether minority ecstasy users are more likely to drop out of school is unclear, and needs further examination. It is likely that persons like the participants in our studies are overlooked by surveillance systems such as the MTF, suggesting that current U.S. estimates of prevalence of club drug use, particularly among minorities, are low.

Congruent with previous studies (Johnston, O’Malley, and Bachman, 2002; Strote, Lee, and Wechsler, 2002), we observed that ecstasy users were young. We observed a significant interaction between injection drug use and race where Hispanic noninjectors and white injectors were significantly more likely, and black injectors were significantly less likely, to have a history of lifetime ecstasy use. We also found that being U.S.-born was an independent correlate of lifetime ecstasy use, but did not observe an interaction between race and country of birth. Previous studies have reported that individuals born in the U.S., and Hispanics in particular (Brindis et al., 1995), have higher rates of drug use as compared non-U.S. born immigrants (Johnson, VanGeest, and Cho, 2002). Further investigation of this finding will be necessary to understand the social environment and context of ecstasy use among U.S. minorities.

We also found that current homelessness was associated with lifetime ecstasy use. This relationship has not been reported previously. A possible explanation for this relationship 
could be that homeless people are more mobile through the city or the country, and therefore have access to different drug markets. Such data are not available in this dataset, but would be an area for additional research. Qualitative data would also further our understanding of this finding.

While the sample studied here is not representative of all minorities or all minority drug users, it does provide evidence for ecstasy use among young black and Hispanic heroin, crack, and cocaine users that is higher than the previously reported prevalences of ecstasy use among minorities. Anecdotal reports suggest that MDMA is being sold on the streets of Harlem and the South Bronx, areas that are predominantly Hispanic and black. The changing venues of club drug use and the evolving club drug trade are beginning to be documented (Community Epidemiology Work Group, 2001). Our findings provide further evidence for availability of club drugs outside their tradition venues.

The burden of "substance abuse" is already high among minority communities in the United States (Galea et al., 2003; Buka, 2002; Harlow, 1990), and the precarious health status of these communities could be further compromised by another "epidemic" of drug use. Our findings highlight the need for further investigation of ecstasy use in minority populations, to determine the extent of use and to understand the posited risk factors and their dimensions, the necessary conditions for them to operate or not, as well as correlates of use among minorities.

\section{Acknowledgments}

This study was partly funded by grants DA13146 and DA12801 from the National Institute on Drug Abuse.

\section{RÉSUMÉ}

Des données recueillies semblent indiquer que l'usage de l'Ecstasy dans les ÉtatsUnis est prédominante parmi les adolescents et les jeunes adultés. Pour étudier l'usage de l'Ecstasy à New York City nous avons ajouté des questions aux oeuvres en cours pour recruter des comsommateurs de l'héroïne et de la cocaïne. Parmi les 715 participants, 58,3\% étaient consommateurs d'injections de drogues (IDUs). L'âge médiane était de de 32 ans (de 17 à 64), 76,4\% étaient mâles, 49.0\% étaient sans abri, 62.4\% étaient Hispaniques et $27.3 \%$ étaient Noirs. 34.5\% n'étaient pas nés dans les États Unis.

En général, 23.4\% ont consommé de l'Ecstasy une fois ou l'autre et 11.9\% l'ont consommée pendant les derniers six mois. Dans l'analyse de régression logistique multivariée, la corrélation de l'usage de l'Ecstasy de toute une vie y compris les jeunes, étant né dans les États Unis, et les sans abri courants. Nous avons observé une interaction considérable entre la consommation de la drogue injectée et la race où, comparés aux non-IDUs Noirs, non-IDUs Hispaniques et IDUs Blancs avaient considérablement une histoire de consommation de drogue pendant toute la vie plus probable tandis que les IDUs Noirs en étaient considérablement moins problables. Ces conclusions sont limités aux personnes qui consomment d'autres drogues mais elles indiquent qu'une investigation plus ample de la consommation de l'Ecstasy dans la population minoritaire est justifiée.

\section{RESUMEN}

Los datos observados nos sugieren que el uso de la droga Éxtasis en los EE. UU. ocurre predominantemente entre los adolescentes blancos y los adultos jóvenes. Para investigar el 
uso de Extasis entre los usuarios de drogas en la ciudad de Nueva York, añadimos preguntas a las formuladas en nuestros esfuerzos actuales para reclutar usuarios de heroína y de cocaína para un estudio. De los 715 participantes reclutados, 58.3\% eran usuarios de drogas por inyección. La mediana de edad era de 32 años, en un grupo que abarcaba desde los 17 a los 64 años; 76.4\% eran varones; $49 \%$ eran desamparados; $62.4 \%$ eran hispanos, y $27.3 \%$ eran negros. $34.5 \%$ nacieron fuera de los EE. UU. En conjunto, $23.4 \%$ de ellos habían consumido Extasis en algún momento de sus vidas, y 11.9\% la habían usado en los últimos 6 meses.

En regresión logística multivariada, los correlatos de uso del Extasis incluyeron una menor edad del usuario, el haber nacido en los EE.UU., y el encontrarse actualmente sin hogar. Observamos una interacción significativa entre el uso de drogas inyectadas y la raza: comparados con los negros no usuarios de drogas inyectadas, los hispanos no usuarios de drogas inyectadas y los blancos usuarios se mostraban significativamente más tendientes al consumo de Éxtasis a lo largo de su vida, en tanto que los negros usuarios de drogas inyectadas aparecían como significativamente menos tendientes a ello.

Estas conclusiones se limitan a personas que consumen otras drogas, pero sugieren que está justificado el realizar investigaciones adicionales sobre el uso de Extasis entre grupos demográficos minoritarios.

\section{THE AUTHORS}

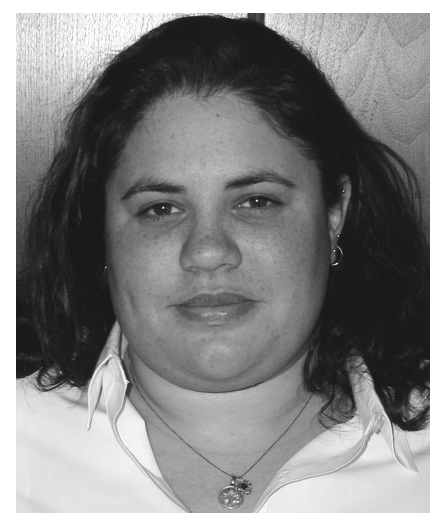

Danielle C. Ompad, Ph.D., is an Investigator at the Center for Urban Epidemiologic Studies at the New York Academy of Medicine. Dr. Ompad completed her M.H.S. and $\mathrm{Ph} . \mathrm{D}$. in infectious disease epidemiology at the Johns Hopkins University School of Public Health. Dr. Ompad has extensive experience in design, conduct, and analysis of community-based cross-sectional and prospective studies focusing on illicit substance use and risky sexual behavior. Currently, Dr. Ompad's work involves assessing adolescent and young adult risk for HIV, HCV, and other blood-borne pathogens.

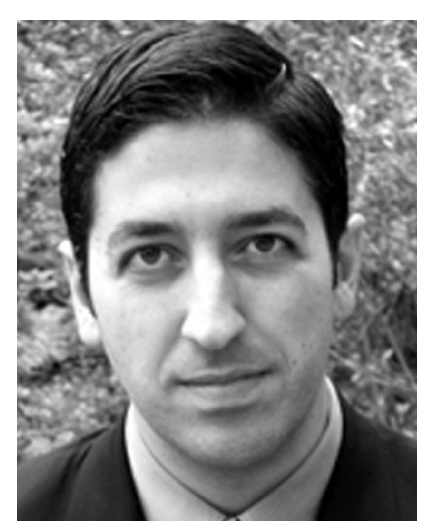

Sandro Galea, M.D., M.P.H., Dr.PH., is a Medical Epidemiologist and Associate Director at the Center for Urban Epidemiologic Studies at the New York Academy of Medicine. He did his graduate training at the Harvard University School of Public Health, the Columbia University Mailman School of Public Health, and at the University of Toronto Medical School, Canada. Dr. Galea is primarily interested in the social and economic determinants of health and risk behavior in urban settings. His work includes basic epidemiologic research, theoretic development, and the application of innovative methods to epidemiologic problems. Dr. Galea is an elected member of the American College of Epidemiology and a fellow of the Royal Institute of Public Health. He is board certified in Family Medicine and Emergency Medicine. He has worked as a clinician in remote rural communities in Northern Canada and in Mudug Region, Somalia. He is a licensed physician in Ontario, Canada and New York State. 

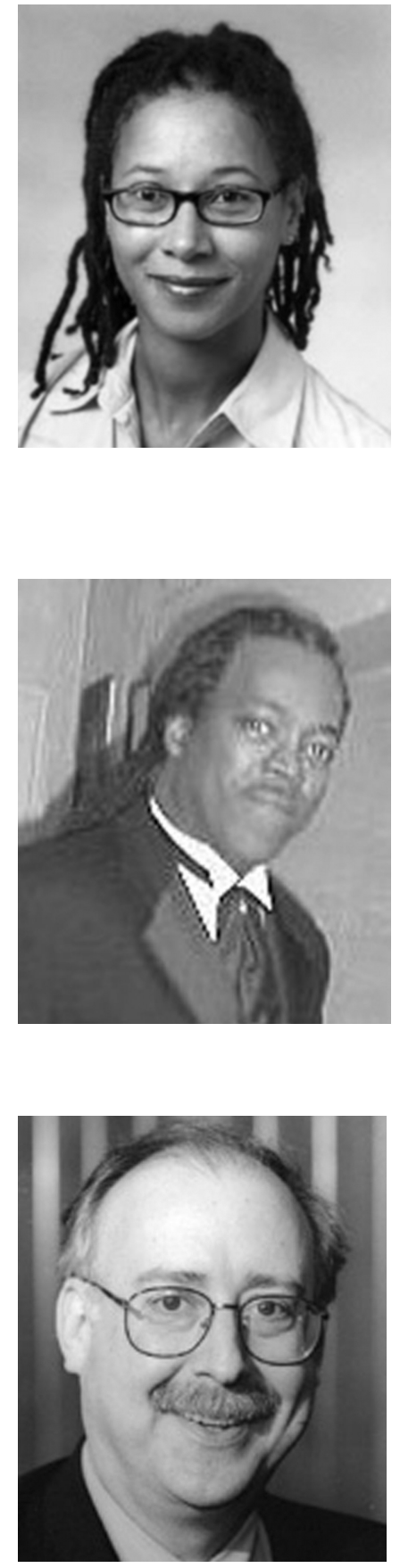

David Vlahov, Ph.D., is Director for the Center for Urban Epidemiologic Studies at The New York Academy of Medicine, Professor of Clinical Epidemiology at the Mailman School of Public Health at Columbia University, and Adjunct Professor in Epidemiology at the Johns Hopkins School of Public Health. He is also Adjunct Professor in Psychiatry at New York University Medical School, Adjunct Professor at Cornell Weill Medical School, and Visiting Professor at the Albert Einstein College of Medicine at Yeshiva University. Dr. Vlahov completed his B.S.N. and M.S. in Nursing at the University of Maryland and a Ph.D. in epidemiology at Johns Hopkins School of Public Health. He has extensive experience in the design, conduct, and analysis of infectious disease and substance abuse epidemiological studies. He is the Editor-in-Chief of the Journal of Urban Health and has been appointed to the National Advisory Council on Drug Abuse within the Department of Health and Human Services. Dr. Vlahov has received funding from the NIH and the CDC to conduct epidemiologic intervention studies of HIV prevention in Harlem and the South Bronx involving young, adult recent consent injection drug users and noninjection drug users. 


\section{References}

Arria, A. M., Yacoubian, G. S., Jr., Fost, E., Wish, E. D. (2002). The pediatric forum: Ecstasy use among club rave attendees. Arch. Pediatr. Adolesc. Med. 156:295-296.

Boyd, C. J., McCaben, S. E., d'Arcy, H. (2003). Ecstasy use among college undergraduates: Gender, race and sexual identity. J. Subst. Abuse. Treat. 24:209-215.

Brindis, C., Wolfe, A. L., McCarter, V., Ball, S., Starbuck-Morales, S. (1995). The associations between immigrant status and risk-behavior patterns in Latino adolescents. J. Adolesc. Health 17:99-105.

Buka, S. L. (2002). Disparities in health status and substance use: Ethnicity and socioeconomic factors. Public Health Rep. 117(Suppl 1):S118-S125.

Colfax, G. N., Mansergh, G., Guzman, R., Vittinghoff, E., Marks, G., Rader, M. et al. (2001). Drug use and sexual risk behavior among gay and bisexual men who attend circuit parties: A venue-based comparison. J. Acquir. Immune. Defic. Syndr. 28:373-379.

Community Epidemiology Work Group. (2001). Epidemiologic trends in drug abuse, Volume 1. Proceedings from the Community Epidemiology Work Group. National Institute on Drug Abuse.

Diaz, T., Des Jarlais, D., Vlahov, D., Perlis, T. E., Edwards, V., Friedman, S. R. et al. (2001a). Factors associated with prevalent hepatitis C: Differences among young adult injection drug users in lower and upper Manhattan, New York City. Am. J. Public. Health 91:23-30.

Diaz, T., Vlahov, D., Greenberg, B., Cuevas, Y., Garfein, R. (2001b). Sexual orientation and HIV infection prevalence among young Latino injection drug users in Harlem. J. Womens. Health Gend. Based Med. 10:371-380.

Galea, S., Ahern, J., Tardiff, K., Leon, A. C., Coffin, P. O., Derr, K. et al. (2003). Racial/ethnic disparities in overdose mortality trends in New York City, 1990-1998. J. Urban. Health 80:201211.

Harlow, K. C. (1990). Patterns of rates of mortality from narcotics and cocaine overdose in Texas, 1976-1987. Public Health Rep. 105:455-462.

Johnson, T. P., VanGeest, J. B., Cho, Y. I. (2002). Migration and substance use: Evidence from the U.S. National Health Interview Survey. Subst. Use Misuse 37:941-972.

Johnston, L. D., O'Malley, P. M., Bachman, J. G. (2002). Monitoring the Future National Survey Results on Drug Use, 1975-2001. Volume I: Secondary School Students (NIH Publication No. 025106). Bethesda, MD: National Institute on Drug Abuse.

Johnston, L. D., O'Malley, P. M., and Bachman, J. G. (2002). Ecstasy use among American teens drops for the first time in recent years, and overall drug and alcohol use also decline in the year after 9/11. Ann Arbor, MI, University of Michigan News and Information Services. http://www.monitoringthefuture.org/pressreleases/02drugpr_complete.pdf (accessed 1216-2002).

Klitzman, R. L., Pope, H. G., Jr., Hudson, J. I. (2000). MDMA (“ecstasy”) abuse and high-risk sexual behaviors among 169 gay and bisexual men. Am. J. Psychiatry 157:1162-1164.

Mansergh, G., Colfax, G. N., Marks, G., Rader, M., Guzman, R., Buchbinder, S. (2001). The Circuit Party Men's Health Survey: Findings and implications for gay and bisexual men. Am. J. Public. Health 91:953-958.

Mattison, A. M., Ross, M. W., Wolfson, T., Franklin, D. (2001). Circuit party attendance, club drug use, and unsafe sex in gay men. J. Subst. Abuse 13:119-126.

Strote, J., Lee, J. E., Wechsler, H. (2002). Increasing MDMA use among college students: Results of a national survey. J. Adolesc. Health. 30:64-72.

Yacoubian, G. S., Jr. (2002). Assessing the temporal relationship between race and ecstasy use among high school seniors. J. Drug. Educ. 32:213-225. 